\title{
In situ transfer of an exogenously isolated plasmid between Pseudomonas spp. in sugar beet rhizosphere
}

\author{
Andrew K. Lilley, ${ }^{1,2}$ John C. Fry, ${ }^{2}$ Martin J. Day ${ }^{2}$ and Mark J. Bailey ${ }^{1}$ \\ Author for correspondence: Mark J. Bailey. Tel: +44 865 512361. Fax: +44 86559962.
}

\footnotetext{
1 Natural Environment Research Council, Institute of Virology and Environmental Microbiology, Mansfield Road, Oxford OX1 3SR, UK

2 School of Pure and Applied Biology, University of Wales College of Cardiff, PO Box 915 , Cardiff CF1 3TL, UK
}

\begin{abstract}
A method for studying plasmid transfer in the rhizosphere is described. This work demonstrates plasmid transfer in an unenclosed rhizosphere under field conditions. The donor (Pseudomonas marginalis 376N) and recipient (Pseudomonas aureofaciens 381R) bacteria and the conjugative mercury resistance plasmid (PQBR11) studied were all isolated from the bacterial community indigenous to sugar beet rhizosphere. Spontaneous nalidixic acid and rifampicin resistant mutants of these bacteria were used as donors and recipients of PQBR11 for in situ matings. Fresh field soil was mixed with donors and recipients to give a soil mating mix (SMM) which was placed underground on the surface of a sugar beet root storage organ. Plasmid transfer in the SMM was determined after $24 \mathrm{~h}$ at frequencies between $5.1 \times 10^{-5}$ and $1.3 \times 10^{-8}$ transconjugants per recipient. Higher transfer frequencies $\left(1.3 \times 10^{-2}\right.$ to $\left.1.7 \times 10^{-6}\right)$ were recorded on the peel adjacent to the SMM. No transfer of mercury resistance was detected in SMM controls incubated at $20^{\circ} \mathrm{C}$ in vitro or placed in soil at distances of more than $5 \mathrm{~cm}$ from plants.
\end{abstract}

Keywords: rhizosphere, plasmid transfer, soil bacteria, Pseudomonas

\section{INTRODUCTION}

The prospect of releasing genetically manipulated microorganisms (GMMOs) into the environment has highlighted the need to evaluate the mechanisms and frequencies of natural gene transfer. Conjugative plasmids are an important means of gene transfer in soil and rhizosphere habitats (Trevors et al., 1987), where the study of the behaviour of indigenous plasmids is of particular interest. As a result of the difficulties normally associated with working in the natural environment, many researchers have used simplified microcosms, laboratory strains or non-indigenous plasmids to model transfer. In aquatic systems, however, plasmid transfer has been studied in unenclosed natural systems using indigenous plasmids (Bale et al., 1988; Fry \& Day, 1990). Similar experiments are needed in terrestrial systems, to assess directly the natural activity of plasmids.

Other work in model or simulated systems typically describes low plasmid transfer frequencies in a range of soils. The transfer frequency can, however, be increased in the presence of roots, by nutrient amendment, or by

Abbreviation: SMM, soil mating mix. soil sterilization (van Elsas et al., 1990; Top et al., 1990; Stotzky, 1989; Klingmüller, 1991). 'These modifications increase the availability of nutrients or reduce competition from other microbiota. In this study we describe the use of the rhizosphere associated with sugar beet storage organs (the beet) to investigate natural plasmid transfer. These root structures can grow to over $3 \mathrm{~kg}$ and support substantially higher bacterial densities than the surrounding soil.

To enable realistic studies of plasmid transfer in the terrestrial environment it was considered essential that only indigenous plasmids and bacteria be used. Consequently, after isolation and characterization, isolates were reintroduced into the sugar beet rhizosphere at environmentally relevant densities to demonstrate and measure the frequency of in situ plasmid transfer.

\section{METHODS}

Bacterial strains, plasmids, culture media and enumeration. The bacterial strains and plasmids used in this study are given in Table 1. All strains were stored at $-70^{\circ} \mathrm{C}$ and cultured on plate count agar (PCA; Oxoid CM463) at $28^{\circ} \mathrm{C}$ amended with the appropriate antibiotics. Selective agents were included in media at the following concentrations unless otherwise stated; rifam- 
Table 1. Bacterial strains and plasmids used in this study

\begin{tabular}{|c|c|c|}
\hline $\begin{array}{l}\text { Strain or } \\
\text { plasmid }\end{array}$ & Characteristics* & $\begin{array}{l}\text { Source or } \\
\text { reference }\end{array}$ \\
\hline \multicolumn{3}{|c|}{ Pseudomonas putida } \\
\hline UWC1 & Rif $^{p}$ & $\begin{array}{l}\text { McClure et al. } \\
(1989)\end{array}$ \\
\hline \multicolumn{3}{|c|}{ Pseudomonas aureofaciens } \\
\hline 381 & & This study \\
\hline $381 \mathrm{R}$ & $\operatorname{Rif}^{r}$ & This study \\
\hline 373 & & This study \\
\hline $373 N$ & $\mathrm{Nal}^{\mathrm{r}}$ & This study \\
\hline $373 R$ & Rif $^{r}$ & This study \\
\hline \multicolumn{3}{|c|}{ Pseudomonas marginalis } \\
\hline 376 & & This study \\
\hline $376 \mathrm{~N}$ & $\mathrm{Nal}^{\mathrm{r}}$ & This study \\
\hline \multicolumn{3}{|c|}{ Pseudomonas fuorescens } \\
\hline 366 & & This study \\
\hline $366 \mathrm{R}$ & Rif $^{r}$ & This study \\
\hline 391 & & This study \\
\hline $391 \mathrm{~N}$ & $\mathrm{Nal}^{\mathrm{r}}$ & This study \\
\hline $391 \mathrm{R}$ & Rif $^{r}$ & This study \\
\hline pQBR11† & $\mathrm{Tra}^{+}, \mathrm{Hg}^{\mathrm{r}}, 294 \mathrm{~kb}$ & This study \\
\hline
\end{tabular}

* Abbreviations used: Rif ${ }^{r}$, rifampicin resistance; $\mathrm{Nal}^{\mathrm{r}}$, nalidixic acid resistance; $\mathrm{Tra}^{+}$, transfer-proficient conjugative plasmid; $\mathrm{Hg}^{\mathrm{r}}$, resistance to mercuric ions. Some other antibiotic resistant mutants of these strains also used (see Results and Discussion).

† Twenty-two other mercury resistance plasmids were also isolated and investigated in this study (see Results and Discussion).

picin (Sigma; $100 \mu \mathrm{g} \mathrm{ml}^{-\mathbf{1}}$ ), nalidixic acid (Sigma; $300 \mu \mathrm{g} \mathrm{ml}^{-\mathbf{1}}$ ) and $\mathrm{HgCl}_{2}(\mathrm{BDH} ; 0 \cdot 1 \mathrm{mM})$. Broth cultures were grown in nutrient broth (NB; Oxoid CM1) overnight in an orbital shaker (190 r.p.m.) at $28{ }^{\circ} \mathrm{C}$. Tryptone Soya Broth Agar (TSBA; Tryptone Soya Broth, Oxoid CM129, and $1.5 \%$, w/v, Oxoid Agar no. 1 L11) was used for filter plate matings and amended with cycloheximide (Sigma; $50 \mu \mathrm{g} \mathrm{m}^{-1}$ ) for the isolation of strains from the rhizosphere. Donors for in situ and soil matings were grown in $\mathrm{NB}$ amended with $\mathrm{HgCl}_{2}(0.05 \mathrm{mM})$.

Bacteria were enumerated by dilution and spread plating for low dilutions or drop plated, three drops at $20 \mu$ l, for higher dilutions, on suitably amended PCA plates. All counts, expressed per gram, were corrected to dry weights (soil at $105^{\circ} \mathrm{C}$, peel at $85^{\circ} \mathrm{C}$ ). Plasmid transfer frequencies were calculated as the final transconjugant count divided by the final recipient count.

Crop management and definitions. The sugar beet were grown at the Oxford University Farm, Wytham, Oxford, UK, in a $10 \mathrm{~m} \times 10 \mathrm{~m}$ plot (map reference SP473088). On 28 April 1992 sugar beet (Beta vulgaris var. Amethyst) pelleted seeds (Germains UK) were sown at $15 \mathrm{~cm}$ intervals. The pellets included the fungicides Thiram, Hymexazol and Methiocarb. An additional row was sown on 2 July 1992. The plot was fertilized at $0 \cdot 15 \mathrm{~kg} \mathrm{~m}^{-2}$ (N:P:K 13:13:20, Hydrofertilisers) and treated with a triazinone beet crop, contact-residual herbicide (Goltex; Bayer) and a contact-ingestion organochlorine insecticide (Gammacol; ICI) $5 \mathrm{~d}$ before sowing. The soil at the site is described as an Evesham Series heavy clay (clay $53.5 \%$, sand $24.9 \%$, silt $21.6 \%$, $\mathrm{pH} 7 \cdot 7$, with organic content $8.5 \%)$. Potted plants were prepared by digging up single fieldgrown plants with the surrounding root soil intact and placing them in $20 \mathrm{~cm}$ pots. These plants were kept outside and grown on for 2-3 weeks before use, and watered from below to maintain field capacity.

Fine peel, taken to represent the rhizoplane, was removed with a scalpel (approximately $40 \mathrm{mg} \mathrm{cm}^{-2}$ ) from the beet after clinging soil had been knocked away. Rhizosphere soil was defined as the soil adhering to and within $5 \mathrm{~mm}$ of the beet. This was sampled by paring soil back to within $5 \mathrm{~mm}$ of the beet and prising or gently scraping off the remaining soil. Fresh field soil was collected at a depth of $7-10 \mathrm{~cm}$ and at least $10 \mathrm{~cm}$ from the nearest plant.

Isolation of bacterial strains from the rhizosphere. Fine peelings of the beet were resuspended at $5 \%(\mathrm{w} / \mathrm{v})$ in quarterstrength Ringer's solution (Oxoid BR52) and shaken (Luckham R100 shaker, 250 r.p.m., room temperature, $20 \mathrm{~min}$ ) or homogenized (Waring Blender, 3 min on ice). Bacterial suspensions were diluted, spread onto TSBA and incubated for $96 \mathrm{~h}$ at $15^{\circ} \mathrm{C}$. Colonies were picked, purified and identified by analysis of methylated fatty acid profiles using the Microbial Identification System (MIS-MIDI, Newark, DE, USA) essentially as described by Thompson et al. (1993). Briefly, $50 \mathrm{mg}$ cells from TSBA plates (incubated $24 \mathrm{~h}, 28^{\circ} \mathrm{C}$ ) were saponified using $\mathrm{NaOH}$ in methanol and then methylated with methanol and HCl. Fatty acid methyl ester derivatives (FAMEs) were extracted with methyl tert-butyl ether and the base washed organic phase stored at $-20^{\circ} \mathrm{C}$. FAMEs were analysed on a Hewlett Packard series II gas chromatograph (5890) using a phenyl methyl silicone capillary column $(25 \mathrm{~m} \times 0.2 \mathrm{~mm} \times$ $0.33 \mu \mathrm{m})$. A pattern recognition algorithm compared FAME profiles with the MIDI-MIS TSBA aerobic data base (version 3.2), naming species and sub-species most like the sample and giving similarity indices. All identifications given had similarity indexes of 0.7 or greater.

Exogenous isolation of conjugative plasmids from the rhizosphere. Conjugative plasmids conferring resistance to $\mathrm{Hg}^{2+}$ were isolated from sugar beet rhizosphere bacteria using the exogenous isolation method (Fry \& Day, 1990) adapted for the rhizosphere. A beet peel homogenate was mixed with an overnight broth culture of Pseudomonas putida UWC1 (1 ml of each) and incubated on a dry TSBA plate at $20^{\circ} \mathrm{C}$ for $24 \mathrm{~h}$. This mating mix was resuspended in $6 \mathrm{ml} 0.1 \times \mathrm{NB}$ and serially diluted onto PCA plates amended with rifampicin and $\mathrm{HgCl}_{2}$ to select for $P$. putida UWC1 transconjugants which had gained plasmids conferring resistance to $\mathrm{Hg}^{2+}$.

Filter plate matings. Overnight cultures $(1 \mathrm{ml})$ in NB of donor and recipient were mixed and deposited onto $25 \mathrm{~mm}$ diameter cellulose nitrate membrane filters (Whatman) and incubated, bacteria side up, on TSBA plates for $24 \mathrm{~h}$ at $20^{\circ} \mathrm{C}$. The filters were vortex-mixed in $10 \mathrm{ml} 0.1 \times \mathrm{NB}$, diluted and enumerated on appropriately amended PCA plates to count donors, recipients and transconjugants.

In situ mating. Overnight cultures of Pseudomonas aureofaciens $381 \mathrm{R}$ in NB (without antibiotics) and Pseudomonas marginalis $376 \mathrm{~N}$ (pQBR11) in $\mathrm{NB}$ amended with $0.05 \mathrm{mM} \mathrm{HgCl}_{2}$ were harvested (Eppendorf microcentrifuge 5415C, 14000 r.p.m., $1 \mathrm{~min}$ ), washed twice and resuspended in $0.85 \%$ saline. Fresh field soil (29-33\% moisture) was mixed with a spatula and divided into $1 \mathrm{~g}$ quantities in sterile universal bottles. Mean initial bacterial concentration in the soil was determined at $9 \cdot 4 \times 10^{5}$ c.f.u. $\mathrm{g}^{-1}(n=6, \mathrm{cV}=114 \%)$. Saline suspensions of donor and recipient cells $(100 \mu$ total) were added to the soil 
(donor first) and mixed with a spatula (final moisture 35-39\%). Each soil mating mix (SMM) was placed, with a spatula, onto a sterile $25 \mathrm{~mm}$ diameter $0.45 \mu \mathrm{m}$ pore size cellulose nitrate membrane filter (Whatman) in a sterile plate and introduced to the rhizosphere of potted field plants or to plants at the field site (transport time $40 \mathrm{~min}$ ). The soil was eased away from the side of the beet using a trowel and a sterile spatula; the inoculated mixture supported on the filter was then pressed down onto the root $7-10 \mathrm{~cm}$ below the surface and the surrounding soil replaced. A replicate SMM filter was similarly placed on the opposite side of the root. After $24 \mathrm{~h}$ the SMMs were recovered. The soil was collected from each filter into a sterile universal bottle, transported to the laboratory and vortex-mixed in $10 \mathrm{ml}$ $0 \cdot 1 \times \mathrm{NB}$ to resuspend bacteria. The peel from the root surface where the SMM had been applied was carefully removed with a scalpel into a microcentrifuge tube. Peelings from the two mating sites on each plant were pooled and vortex-mixed in $1 \mathrm{ml}$ $0 \cdot 1 \times \mathrm{NB}$. Peel and SMM suspensions were diluted and the bacteria enumerated on PCA plates amended with (i) nalidixic acid and $\mathrm{HgCl}_{2}$ for donors, (ii) rifampicin for recipients, or (iii) rifampicin and $\mathrm{HgCl}_{2}$ for transconjugants. The identity of a subsample of transconjugants $(60-70$ colonies) was initially confirmed by growth on fresh PCA amended with rifampicin and $\mathrm{HgCl}_{2}$ and lack of growth on PCA amended with nalidixic acid and $\mathrm{HgCl}_{2}$.

Control experiments were as follows: (i) SMMs placed on filters in universal bottles and incubated at $20^{\circ} \mathrm{C}$ for $24 \mathrm{~h}$, (ii) SMMs placed on filters in Petri dishes and incubated at room temperature for $1.5 \mathrm{~h}$, and (iii) SMMs held between pairs of filters placed in the soil $5-10 \mathrm{~cm}$ from the experimental plant. Other controls determined the rate of mutation of donors and recipients to transconjugant phenotype.

Soil matings. Donot and recipient cells from overnight broth cultures were washed twice, resuspended in $0.85 \%$ saline and mixed $\left(100 \mu \mathrm{l} \mathrm{g}^{-1}\right)$ with fresh field soil in universal bottles. Nutrient-amended soil matings were included, using overnight cultures washed and resuspended in $\mathrm{NB}$ and mixed with the soil. The soil matings were incubated for $24 \mathrm{~h}$ at $20^{\circ} \mathrm{C}$, vortex-mixed $10 \%(\mathrm{w} / \mathrm{v})$ in $0.1 \times \mathrm{NB}$, diluted and plated onto appropriately amended PCA plates to count donors, recipients and transconjugants.

Plasmid isolation and restriction endonuclease digestion. Plasmid presence was confirmed using the method of Rochelle et al. (1986) as modified from Kado \& Liu (1981) for plasmid extraction and visualization on agarose gels. Plasmid DNA for restriction endonuclease digestion was prepared by the sucrose gradient method of Wheatcroft \& Williams (1981) and digested using enzymes supplied by Pharmacia in accordance with the manufacturer's instructions. Electrophoresis was performed through $0.6 \%(\mathrm{w} / \mathrm{v})$ agarose gels in $1 \times \mathrm{TBE}$ buffer $(0.089 \mathrm{M}$ Tris/borate, $0.002 \mathrm{M}$ EDTA) at $5 \mathrm{~V} \mathrm{~cm}^{-1}$.

Isolation of proteins and sodium dodecyl sulphate-polyacrylamide gel electrophoresis (SDSPAGE). Recipient and donor cellular protein patterns were compared by SDS-PAGE on $6 \%$ or $10 \%(\mathrm{w} / \mathrm{v})$ polyacrylamide gels (Laemmli, 1970). Cellular proteins were isolated from overnight broth cultures using the method of Xu \& Gross (1988). Briefly, $250 \mu \mathrm{l}$ overnight broth culture was centrifuged and the pellet resuspended in $200 \mu \mathrm{l}$ water and $250 \mu \mathrm{l}$ sample buffer $(0 \cdot 125 \mathrm{M}$ Tris/HCl, $\mathrm{pH} 6.8 ; 4 \%(\mathrm{w} / \mathrm{v})$ SDS; $20 \%, \mathrm{v} / \mathrm{v}$, glycerol; $1.4 \mathrm{M} 2$-mercaptoethanol). After $1 \mathrm{~h}$ incubation at $37^{\circ} \mathrm{C}$ the mixture was centrifuged (Eppendorf microcentrifuge 5415C, 14000 r.p.m., $1 \mathrm{~min}$ ) and $20 \mu \mathrm{l}$ supernatant containing soluble protein loaded per well. Protein bands were visualized by staining with Coomassie Brilliant Blue.
Statistical analysis. Coefficients of variation (Cv), one-way analysis of variance (ANOvA), Bartlet's Box $F$ test, Cochran's $C$ test, Hartley's $F_{\max }$ test and other statistical tests were calculated using Unistat version 4.56. For one-way ANOvA, count data were transformed by $\log _{10} x$ and frequency data by $\log _{10}$ $\left(x+1 \times 10^{-9}\right)$ to ensure homogeneity of variances.

\section{RESULTS AND DISCUSSION}

\section{Isolation of strains and plasmids}

From a collection of bacteria isolated from the sugar beet rhizoplane on TSBA and identified by fatty acid analysis, 11 pseudomonads were chosen as potential donors or recipients for in situ matings. These were three strains of $P$. aureofaciens, two of Pseudomonas fuorescens, two of $P$. marginalis, two of Pseudomonas putida, and two of Pseudomonas syringae. Spontaneous rifampicin and nalidixic acid resistant strains were selected where possible, grown overnight in broth and quantitatively plated to confirm stable resistance. One isolate gave only a nalidixic acid resistant strain $(376 \mathrm{~N})$, two gave only rifampicin resistant strains (381R, 366R), and two gave strains of both resistances (373N, 373R, 391N, 391R) (Table 1). Stable nalidixic acid and rifampicin resistant strains were evaluated as potential donors and recipients respectively.

Twenty-three mercury resistance plasmids were exogenously isolated from peel homogenates in three independent experiments using $P$. putida UWC1 as a recipient. Twelve of these plasmids (chosen to include plasmids from each experiment) were transferred by conjugation from $P$. putida UWC1 into the potential donor (nalidixic acid resistant) strain $376 \mathrm{~N}$ (transfer frequencies $1.5 \times 10^{-3}-1 \cdot 0$ ) by filter plate matings. Similarly, transfer of seven of these plasmids was attempted from $P$. putida UWC1 to $373 \mathrm{~N}$; five transferred $\left(1.6 \times 10^{-6}-4.0 \times 10^{-4}\right)$ and two did not (limits of detection $4.0 \times 10^{-9}$ and $\left.1.7 \times 10^{-9}\right)$. Transfer was attempted for only seven of the 12 plasmids as it became apparent that $373 \mathrm{~N}$ was a poor recipient for some of the plasmids and that transfer from it to the chosen recipients was poor. No transfer to $391 \mathrm{~N}$ by five of the 12 plasmids could be detected despite low limits of detection in three cases $\left(3.4 \times 10^{-10}-8.1 \times 10^{-10}\right)$

Those plasmids in $376 \mathrm{~N}$ and $373 \mathrm{~N}$ were transferred in filter matings to the four available rifampicin resistant strains to identify a high transfer frequency combination of donor, recipient and plasmid. No plasmid transfer could be detected to $366 \mathrm{R}$ (three plasmids from $373 \mathrm{~N}$ and four from $376 \mathrm{~N}$ ) or to $391 \mathrm{R}$ (five plasmids from $373 \mathrm{~N}$ and four from $376 \mathrm{~N}$ ). Plasmid transfer frequencies to $381 \mathrm{R}$ and $373 \mathrm{R}$ are given in Table 2. Isogenic transfer from $373 \mathrm{~N}$ to $373 \mathrm{R}$ was not considered because of the potential difficulties of differentiating between donor and recipient cells from in situ matings.

From the combinations listed in Table 2, the donor $P$. marginalis $376 \mathrm{~N}$ containing $\mathrm{PQBR} 11$ and the recipient $P$. aureofaciens $381 \mathrm{R}$ were chosen for in situ mating experiments because they gave a high transfer frequency of $4.4 \times 10^{-3}(n=2)$ in these preliminary experiments and because the bacteria could be readily distinguished. 
Table 2. Comparison of filter plate mating frequencies for 12 exogenously isolated mercury resistance plasmids in three possible pairings of donor and recipient pseudomonad strains

\begin{tabular}{|c|c|c|c|}
\hline \multirow[t]{2}{*}{ Plasmid } & \multicolumn{3}{|c|}{$\begin{array}{l}\text { Plasmid transfer frequency* }(T / R) \text { for } \\
\text { different donor and recipient combinations }\end{array}$} \\
\hline & $376 \mathrm{~N} \times 381 \mathrm{R}$ & $376 \mathrm{~N} \times 373 \mathrm{R}$ & $373 \mathrm{~N} \times 381 \mathrm{R}$ \\
\hline pQBR2 & $6 \cdot 0 \times 10^{-5}$ & $1.6 \times 10^{-5}$ & $5 \cdot 4 \times 10^{-6}$ \\
\hline pQBR3 & $3 \cdot 2 \times 10^{-4}$ & ND & $9 \cdot 5 \times 10^{-6}$ \\
\hline pQBR4 & $1.2 \times 10^{-4}$ & $7 \cdot 6 \times 10^{-5}$ & ND \\
\hline pQBR5 & $2 \cdot 0 \times 10^{-4}$ & ND & ND \\
\hline pQBR6 & $9.3 \times 10^{-5}$ & $1.1 \times 10^{-5}$ & $3.0 \times 10^{-6}$ \\
\hline PQBR7 & $1.5 \times 10^{-3}$ & $4.7 \times 10^{-5}$ & ND \\
\hline pQBR10 & $1 \cdot 2 \times 10^{-4}$ & ND & $4.5 \times 10^{-5}$ \\
\hline PQBR11 & $4.4 \times 10^{-3}$ & $7 \cdot 4 \times 10^{-6}$ & $4.3 \times 10^{-5}$ \\
\hline pQBR14 & $1.6 \times 10^{-3}$ & ND & ND \\
\hline PQBR19 & $2.8 \times 10^{-5}$ & $4.9 \times 10^{-7}$ & ND \\
\hline PQBR23 & $5 \cdot 3 \times 10^{-5}$ & $3.2 \times 10^{-5}$ & $2.3 \times 10^{-7}$ \\
\hline PQBR24 & $5 \cdot 4 \times 10^{-5}$ & ND & $1.6 \times 10^{-7}$ \\
\hline
\end{tabular}

* All frequencies are the mean of two independent experiments expressed as transconjugants $(\mathrm{T})$ per recipient $(\mathrm{R})$ between combinations of $P$. marginalis $376 \mathrm{~N}$ and $P$. aureofaciens $381 \mathrm{R}$ or $373 \mathrm{R}$. ND, Not determined.

The mean transfer frequency of pQBR 11 between $376 \mathrm{~N}$ and $381 \mathrm{R}$, estimated from further filter plate matings, was $3.3 \times 10^{-4}$ transconjugants per recipient $(n=13$, $\mathrm{CV}=235 \%)$.

Rifampicin and nalidixic acid resistance markers were chosen because they allowed clean selection from rhizosphere bacteria, as resistance to these antibiotics was rare in indigenous bacteria $\left(<1 \times 10^{-9}\right)$. Rifampicin selection was preferred for recipients as this antibiotic performed better when spreading greater amounts of homogenate on plates to select transconjugants at low densities. Stable rifampicin resistant strains could not be generated from the nalidixic acid resistant donor $376 \mathrm{~N}\left(<1 \times 10^{-10}\right)$, further improving the sensitivity of transconjugant selection.

Mercury resistance plasmids were chosen for this study as they are common in terrestrial environments (Kelly \& Reanney, 1984) and gave unambiguous selection against environmental backgrounds. Typically $1.9 \% \quad(n=8$, $\mathrm{CV}=92 \%)$ of cultured beet rhizoplane bacteria were able to grow in the presence of $0.1 \mathrm{mM} \mathrm{HgCl}$. However, no sugar beet rhizosphere bacteria with resistance to both mercury and rifampicin were isolated $\left(<1 \times 10^{-10}\right)$. The reason for the prevalence of mercury resistance is uncertain because the experimental site has no known history of mercury pollution.

\section{In situ mating experiments}

In situ mating experiments between 376N(pQBR11) and $381 \mathrm{R}$ on three potted and three field plants demonstrated plasmid transfer in 10 out of 12 occasions at frequencies
Table 3. Transfer frequencies (transconjugants per recipient) of PQBR11 between $P$. marginalis $376 \mathrm{~N}$ and $P$. aureofaciens $381 \mathrm{R}$ from in situ matings in the rhizosphere of sugar beet

Experiments 1-3 were on potted plants outside at soil temperatures of 19 or $20^{\circ} \mathrm{C}$ and experiment 4 was on field plants at $15^{\circ} \mathrm{C}$. All matings were for $24 \mathrm{~h}$ with two replicates per plant. Peel mating transfer frequencies are for peel pooled from two matings on the same plant. The mean coefficient of variation within replicate transfer frequencies was $129 \%$.

\begin{tabular}{|c|c|c|c|c|c|}
\hline \multirow[t]{2}{*}{$\begin{array}{c}\text { Expt } \\
\text { no. }\end{array}$} & \multirow[t]{2}{*}{$\begin{array}{c}\text { Plant } \\
\text { no. }\end{array}$} & \multirow[t]{2}{*}{ Source* } & \multirow[t]{2}{*}{$\begin{array}{l}\text { Transfer } \\
\text { frequency }\end{array}$} & \multicolumn{2}{|c|}{$\begin{array}{c}\text { Total count of } \\
\text { donors and } \\
\text { recipients } \\
\left.\text { (c.f.u. } \mathbf{g}^{-1}\right) \dagger\end{array}$} \\
\hline & & & & Initial & Final \\
\hline \multirow[t]{2}{*}{1} & 1 & SMM & $<4.5 \times 10^{-7}$ & $1.5 \times 10^{8}$ & $2.0 \times 10^{7}$ \\
\hline & 1 & SMM & $2.4 \times 10^{-6}$ & $1.5 \times 10^{9}$ & $3.9 \times 10^{8}$ \\
\hline \multirow[t]{3}{*}{2} & 2 & SMM & $2.1 \times 10^{-7}$ & $2 \cdot 1 \times 10^{9}$ & $2.7 \times 10^{9}$ \\
\hline & 2 & SMM & $2 \cdot 7 \times 10^{-6}$ & $2.1 \times 10^{9}$ & $2 \cdot 8 \times 10^{9}$ \\
\hline & 2 & Peel & $1.3 \times 10^{-2}$ & NA & $2 \cdot 4 \times 10^{7}$ \\
\hline \multirow[t]{3}{*}{3} & 3 & SMM & $1.3 \times 10^{-8}$ & $2 \cdot 4 \times 10^{8}$ & $9 \cdot 6 \times 10^{8}$ \\
\hline & 3 & SMM & $4.4 \times 10^{-7}$ & $2 \cdot 4 \times 10^{8}$ & $6.1 \times 10^{8}$ \\
\hline & 3 & Peel & $1.7 \times 10^{-6}$ & NA & $8.8 \times 10^{9}$ \\
\hline \multirow[t]{3}{*}{4} & 4 & SMM & $2 \cdot 2 \times 10^{-7}$ & $3.8 \times 10^{8}$ & $1.3 \times 10^{9}$ \\
\hline & 4 & SMM & $1.6 \times 10^{-8}$ & $3.8 \times 10^{8}$ & $5.9 \times 10^{9}$ \\
\hline & 4 & Peel & $4.2 \times 10^{-5}$ & $\mathrm{NA}$ & $3.5 \times 10^{8}$ \\
\hline \multirow[t]{3}{*}{4} & 5 & SMM & $4.8 \times 10^{-6}$ & $3.8 \times 10^{7}$ & $2.3 \times 10^{8}$ \\
\hline & 5 & SMM & $5.1 \times 10^{-5}$ & $3.8 \times 10^{7}$ & $1.5 \times 10^{8}$ \\
\hline & 5 & Peel & $3.8 \times 10^{-4}$ & NA & $3.5 \times 10^{8}$ \\
\hline \multirow[t]{3}{*}{4} & 6 & SMM & $3 \cdot 2 \times 10^{-6}$ & $3.8 \times 10^{6}$ & $4.3 \times 10^{7}$ \\
\hline & 6 & SMM & $<4.8 \times 10^{-7}$ & $3.8 \times 10^{6}$ & $4.3 \times 10^{7}$ \\
\hline & 6 & Peel & $5 \cdot 0 \times 10^{-4}$ & $\mathrm{NA}$ & $7 \cdot 7 \times 10^{7}$ \\
\hline
\end{tabular}

* SMM, soil mating mixes, fresh field soil mixed with donor and recipient bacteria applied directly to the root surface; Peel, removed from the root under the SMM.

†NA, Not applicable, as initial counts could not be made on peel at time of SMM application.

ranging from $5.1 \times 10^{-5}$ to $1.3 \times 10^{-8}$ (Table 3). Transfer frequencies on the peel $\left(1.3 \times 10^{-2}\right.$ to $\left.1.7 \times 10^{-6}\right)$ were higher than those from the corresponding SMM (Table 3 ). These elevated transfer frequencies may result from greater transfer between bacteria colonizing or growing on the rhizoplane or from faster growth of transconjugants on the peel.

The large variation $(\mathrm{cv}=129 \%)$ between replicate mating experiments prevented the detection of significant differences $(P=0.58)$ between plants, such as between those sampled at different stages of development or at different soil temperatures. Jacobs et al. (1985) have shown that the beet rhizoplane is not a uniform habitat but has increased bacterial activity associated with a 


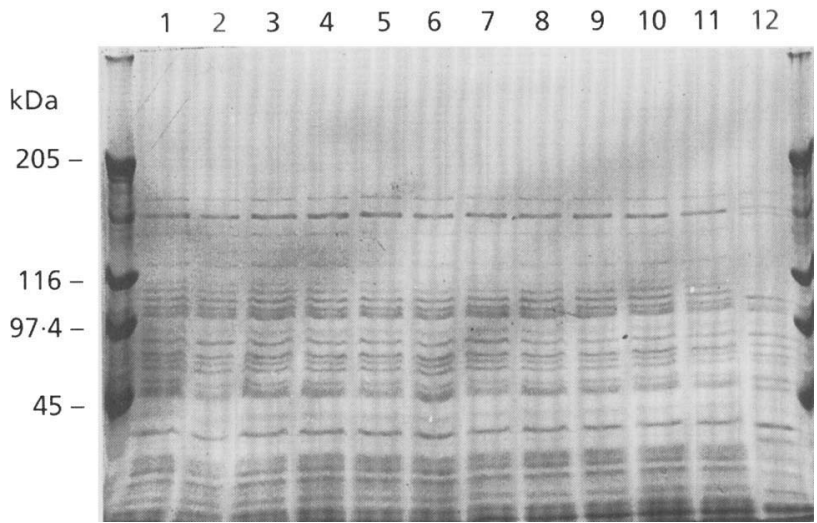

Fig. 1. Soluble cellular protein profiles of transconjugant bacteria isolated from in situ mating, experiment 4. Lanes: $1-10, P$. aureofaciens $381 \mathrm{R}$ transconjugants; $11,381 \mathrm{R}$ culture used as recipient; $12, P$. marginalis $376 \mathrm{~N}(\mathrm{pQBR} 11)$ culture used as donor. Comparison of band patterns in lanes 1-10 with lane 11 confirms the identity of these transconjugants as 381R. Cellular extracts were separated on $10 \%$ SDS-PAGE and stained with Coomassie Brilliant Blue.

vertical zone of secondary root emergence. Of necessity the SMMs were positioned close to this zone and an unequal association with it may have contributed to the 10 - to 35 -fold differences found between the transfer frequencies of replicates.

\section{Confirmation of selection markers}

Since the work described here relied on isolating transconjugants from the environment it was essential to confirm that the selection markers functioned correctly. Ten putative transconjugants per experiment were chosen at random and examined by SDS-PAGE analysis of soluble cellular proteins to confirm that they were the recipient strain 381R (Fig. 1). Plasmids were extracted from at least five transconjugants for each mating experiment and analysed by restriction endonuclease digestion to confirm their identity as PQBR11 (Fig. 2). SDS-PAGE and plasmid profiling were reliable methods for confirming the identity of transconjugants isolated on selection plates. Plasmid analysis also confirmed that the plasmid transferred was PQBR11 and not another indigenous mercury resistance plasmid.

\section{Control experiments and the influence of the rhizosphere}

Plasmid transfer was not detected in any of the SMM control experiments in vitro $\left(<1.2 \times 10^{-8}\right)$, in situ more than $5 \mathrm{~cm}$ from the plants $\left(<1.6 \times 10^{-8}\right)$, or after $1.5 \mathrm{~h}$ mating at room temperature $\left(<8 \cdot 0 \times 10^{-9}\right)$, used to simulate transport conditions. The transfer of $\mathrm{PQBR} 11$ between $376 \mathrm{~N}$ and $381 \mathrm{R}$ could not be detected after $24 \mathrm{~h}$ at $20^{\circ} \mathrm{C}\left(<2.26 \times 10^{-9}\right)$ in normal soils in vitro. However, after soil amendment with nutrient broth $\left(0.1 \mathrm{ml} \mathrm{g}^{-1}\right)$ transfer frequencies of $1.1 \times 10^{-6}(n=3, \mathrm{Cv}=63 \%)$ were observed.

The failure to detect transconjugants in all the control soil mating experiments clearly demonstrated the positive

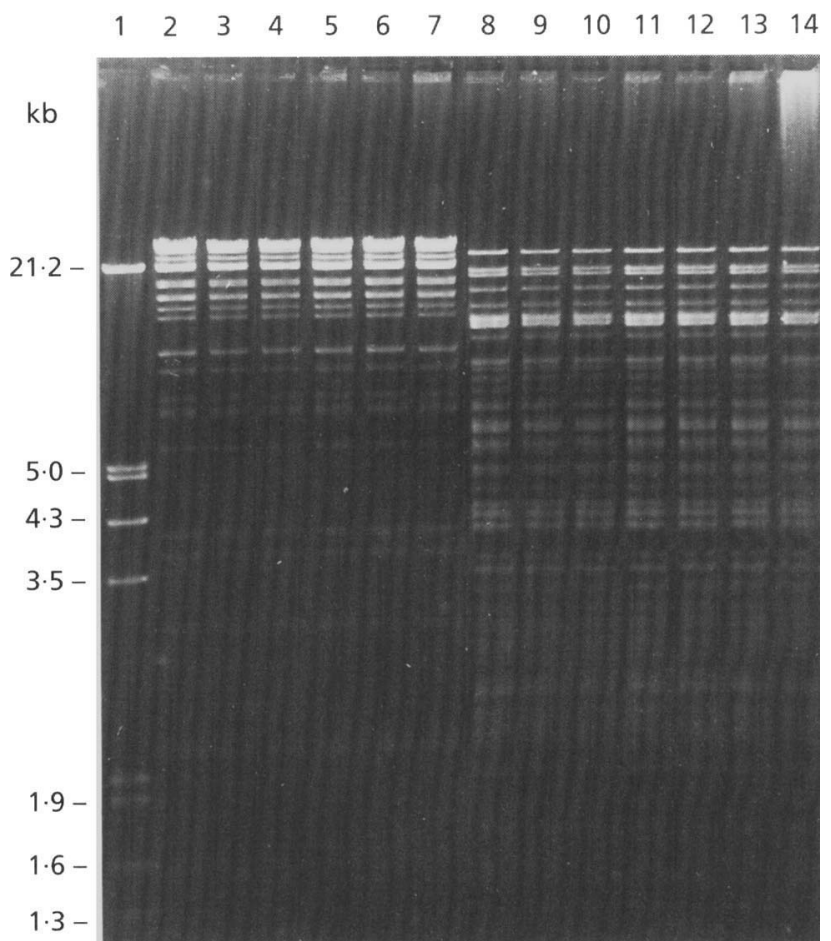

Fig. 2. Restriction digests of pQBR11 DNA isolated from $376 \mathrm{~N}$ (donor) and $381 \mathrm{R}$ transconjugants derived from in situ rhizosphere matings. Lanes: 1, EcoRl/HindIII digest of $\lambda$ bacteriophage DNA; 2 , Xbal digest of pQBR11 isolated from the donor in experiment $4 ; 3-7, X b a l$ digest of PQBR11 isolated from five transconjugants in experiment $4 ; 8-13$, as for lanes 2 to 7 , but Xhol digests; $14, X$ hol digest of pQBR11 from the original plasmid isolation.

influence of the rhizosphere in promoting plasmid transfer. This effect has also been demonstrated in microcosm experiments using wheat rhizospheres (van Elsas et al., 1988) for investigating transfer of the clinically isolated plasmid RP4 (Datta et al., 1971) between introduced bacteria. Increased plasmid transfer in nutrient-enriched soils has been observed previously (Stotzky, 1989; Top et al., 1990; Wellington et al., 1990; Klingmüller, 1991). Although the mechanisms by which the rhizosphere promotes plasmid transfer have not been resolved, it is likely that nutrients play a key role. Plant root exudates can account for up to $40 \%$ of carbon fixed by photosynthesis (Whipps, 1990), which results in a rhizosphere of increased bacterial density and in more metabolically active populations (Zagallo \& Katznelson, 1957). These nutrient-enhanced sites can also attract motile bacteria (Bashan, 1986).

The fall in plasmid transfer frequencies observed between the peel and rhizosphere soil may be related to a declining concentration of nutrient exudates away from the root. Transfer frequencies on the peel were higher than those in nutrient-amended soil. This may also relate to nutrient availability, as the bacteria in amended soil were growing on a declining nutrient base. Rochelle et al. (1989) have shown that mercury resistance plasmid transfer frequencies between pseudomonads were dependent on the nutrient concentration in the mating plate medium up to 
$3.5 \mathrm{~g} \mathrm{C}^{-1}$. Nutrient availability affects the growth rate and metabolic condition of bacteria, which are considered to be significant factors in plasmid transfer. Nonetheless, no correlation between increase in bacterial numbers and transfer frequency was found and no simple relationship between nutrients, growth and transfer frequency could be determined. Other factors which may also affect transfer frequencies include the influence of soil and root surfaces on conjugation, or the plasmid itself may improve the competence of recipients on the peel. Clearly additional studies are needed to resolve the mechanisms of thizosphere influence on plasmid transfer.

\section{Experimental methods}

To achieve realistic mating conditions the SMM inocula were applied at densities typical of rhizosphere soils. Fresh field soil, with lower bacterial counts $\left(9 \cdot 4 \times 10^{5}\right.$ c.f.u. $\left.\mathrm{g}^{-1}, n=6, \mathrm{cv}=114 \%\right)$ than rhizosphere soil, was used for SMMs to avoid increasing bacterial densities above those normally found in the rhizosphere.

In situ transfer frequencies in the SMMs were recorded at final densities for the introduced bacteria ranging from $4.3 \times 10^{7}$ to $5.9 \times 10^{9}$ c.f.u. $\mathrm{g}^{-1}$ (Table 3 ). This range was similar to that in the natural sugar beet rhizosphere soil $\left(1.2 \times 10^{7}\right.$ to $2.3 \times 10^{8}$ c.f.u. $\mathrm{g}^{-1}$; mean $=1 \cdot 1 \times 10^{8}$ c.f.u. $\mathrm{g}^{-1}, n=6, \mathrm{CV}=40 \%$ ). In situ transfer was also observed on the beet surface, where final bacterial densities of $2.4 \times 10^{7}$ to $8.8 \times 10^{9}$ c.f.u. $\mathrm{g}^{-1}$ were recorded (Table 3) . Normal bacterial densities on the peel averaged $7 \cdot 7 \times 10^{8}$ c.f.u. $\mathrm{g}^{-1}(n=11, \mathrm{cV}=82 \%)$ on other field plants sampled during the period of the experiments. Further experiments are planned where the numbers of donors in the SMM are reduced to the densities of bacteria expressing mercury resistance $\left(2 \times 10^{6}\right.$ c.f.u. $\left.\mathrm{g}^{-1}\right)$.

Bacterial counts were similar (no significant difference, $P=0.32)$ in field plant rhizosphere soil $(1.1 \times$ $10^{8}$ c.f.u. $\mathrm{g}^{-1}, n=6, \mathrm{CV}=40 \%$ ) and potted plant rhizosphere soil $\left(1.35 \times 10^{8}\right.$ c.f.u. $\left.\mathrm{g}^{-1}, n=6, \mathrm{cv}=29 \%\right)$. As described above, no significant differences in plasmid transfer frequency on field plants and potted plants were detected. This indicates that potted field plants are suitable experimental models for studying plasmid transfer in the rhizosphere.

Although this in situ method does not exactly simulate natural conditions it does allow the precise control of inoculum density and its placement in an otherwise natural rhizosphere. This provides an effective model with which to realistically study factors that influence conjugation in the rhizosphere. Factors which can be directly evaluated with this method include plant age, plant condition, and position on the root. Prior acclimatization of donor and recipient on separate roots should also be considered. The experimental approach described here provides insights into the behaviour of a natural system and allows microcosm results to be tested in the field. Although untested, by the production of smaller SMMs and careful attention to their placement, this method could be applicable to other plants with substantial roots.

\section{Experimental variables}

Experimental variables likely to have an influence on plasmid transfer in natural environments (Rochelle et al., 1989) were examined during in situ experiments. No trends could be detected between transfer frequency and temperature $\left(15-20^{\circ} \mathrm{C}\right)$, soil moisture $(29-33 \%)$, increase in mating populations, beet weight $(62-360 \mathrm{~g})$ or plant age (54-92 d). Initial donor to recipient (D:R) ratios in the SMMs ranged from 0.16 to 1.4 and at the end of the matings from 0.4 to $1 \cdot 6$. No correlations could be found between final $D: R$ ratio or initial SMM mating densities and transfer frequency.

\section{Conclusions}

The results presented here describe in situ, conjugative plasmid transfer using both natural isolates and an indigenous plasmid in the rhizosphere of sugar beet. The observed frequencies indicate that environmental plasmid transfer may not be an uncommon event provided bacteria are present in appropriate habitats. The method described allows for the realistic study of the factors that influence in situ plasmid transfer. Such studies should lead to a better understanding of plasmid ecology and permit the development of models for predicting likely frequencies of gene transfer in the terrestrial environment.

\section{ACKNOWLEDGEMENT}

A.K. L. was supported by a NERC-CASE studentship award.

\section{REFERENCES}

Bale, M. J., Fry, J. C. \& Day, M. J. (1988). Novel method for studying plasmid transfer in undisturbed river epilithon. $A p p l$ Environ Microbiol 54, 2756-2758.

Bashan, Y. (1986). Migration of the rhizosphere bacteria $A z^{0-}$ spirillum brasilense and Pseudomonas fuorescens towards wheat roots in the soil. J Gen Microbiol 132, 3407-3414.

Datta, N., Hedges, R. W., Shaw, E. J., Sykes, R. B. \& Richmond, M. H. (1971). Properties of an R-factor from Pseudomonas aeruginosa. J Bacteriol 108, 1244-1249.

van Elsas, J. D., Starodub, M. E. \& Trevors, J. T. (1988). Bacterial conjugation between pseudomonads in the rhizosphere of wheat. FEMS Microbiol Ecol 53, 299-306.

van Elsas, J. D., Trevors, J. T., Starodub, M. E. \& van Overbeek, L. S. (1990). Transfer of plasmid RP4 between Pseudomonads after introduction into soil - influence of spatial and temporal aspects of inoculation. FEMS Microbiol Ecol 73, 1-11.

Fry, J. C. \& Day, M. J. (1990). Plasmid transfer in the epilithon. In Bacterial Genetics in Natural Environments, pp. 55-80. Edited by J. C. Fry \& M. J. Day. London: Chapman \& Hall.

Jacobs, M. J., Bugbee, W. M. \& Gabrielson, D. A. (1985). Enumeration, location, and characterisation of endophytic bacteria within sugar beet roots. Can J Bot 63, 1262-1265.

Kado, C. I. \& Liu, S. T. (1981). Rapid procedure for detection and isolation of large and small plasmids. J Bacteriol 145, 1365-1373.

Kelly, W. J. \& Reanney, D. C. (1984). Mercury resistance among soil bacteria - ecology and transferability of genes encoding resistance. Soil Biol Biochem 16, 1--8. 
Klingmüller, W. (1991). Plasmid transfer in natural soil - a case by case-study with nitrogen-fixing Enterobacter. FEMS Microbiol Ecol 85, 107-115.

Laemmli, U. K. (1970). Cleavage of structural proteins during the assembly of the head of bacteriophage T4. Nature 227, 680-685.

McClure, N. C., Weightman, A. J. \& Fry, J. C. (1989). Survival of Pseudomonas putida UWC1 containing cloned catabolic genes in a model activated-sludge unit. Appl Environ Microbiol 55, 2627-2634.

Rochelle, P. A., Bale, M. J., Day, M. J. \& Fry, J. C. (1986). An accurate method for estimating sizes of small and large plasmids and DNA fragments by gel-electrophoresis. J Gen Microbiol 132, 53-59.

Rochelle, P. A., Fry, J. C. \& Day, M. J. (1989). Factors affecting conjugal transfer of plasmids encoding mercury resistance from pure cultures and mixed natural suspensions of epilithic bacteria. $J$ Gen Microbiol 135, 409-424.

Stotzky, G. (1989). Gene transfer among bacteria in soil. In Gene Transfer in the Environment, pp. 165-222. Edited by S. B. Levy \& R. V. Miller. New York: McGraw-Hill.

Thompson, I. P., Bailey, M. J., Ellis, R. J. \& Purdy, K. J. (1993). Subgrouping of bacterial populations by cellular fatty acid composition. FEMS Microbiol Ecol 102, 75-84.

Top, E., Mergeay, M., Springael, D. \& Verstraete, W. (1990). Gene escape model-transfer of heavy-metal resistance genes from
Escherichia coli to Alcaligenes eutrophus on agar plates and in soil samples. Appl Environ Microbiol 56, 2471-2479.

Trevors, J. T., Barkay, T. \& Bourquin, A. W. (1987). Gene-transfer among bacteria in soil and aquatic environments - a review. Can J Microbiol 33, 191-198.

Wellington, E. M. H., Cresswell, N., Herron, P. R., Clewlow, L. J., Saunders, V.A. \& Wipat, A. (1990). Gene transfer between streptomycetes in soil. In Bacterial Genetics in Natural Environments, pp. 216-230. Edited by J. C. Fry \& M. J. Day. London: Chapman \& Hall.

Wheatcroft, R. \& Williams, P. A. (1981). Rapid methods for the study of both stable and unstable plasmids in Pseudomonas. J Gen Microbiol 124, 433-437.

Whipps, J. M. (1990). Carbon economy. In The Rhizosphere, pp. 59-98. Edited by J. M. Lynch. Chichester: John Wiley.

Xu, G. W. \& Gross, D. C. (1988). Physical and functional analyses of the SyrA and SyrB genes involved in syringomycin production by Pseudomonas syringae pv. syringae. J Bacteriol 170, 5680-5688.

Zagallo, A. C. \& Katznelson, H. (1957). Metabolic activity of bacterial isolates from wheat rhizosphere and control soil. J Bacteriol 73, 760-764.

Received 17 March 1993; revised 15 June 1993; accepted 8 July 1993. 